\title{
CONSTRUÇÃO DAS ESCOLAS FAMÍLIAS AGRÍCOLAS NO BRASIL: ensino médio e educação profissional
}

João Batista Pereira de Queiroz

Curso: Doutorado em Sociologia

Data de defesa da tese: 29 de março de 2004

Orientador: Prof. Dr. Yves Chaloult

\section{Resumo}

Análise sócio-histórica do surgimento e o desenvolvimento das Escolas Famílias Agrícolas de Ensino Médio e Educação Profissional (EFAs de EM e EP), que surgiram no Brasil no final da década de 60, no Estado do Espírito Santo, trabalhando com a escolaridade em nível fundamental. Em 1976, iniciou-se a oferta de Ensino Médio e Educação Profissional na EFA de Olivânia, município de Anchieta/ ES; na década de 80, surgiram mais duas; e, entre os anos 1991 e 2002, surgiram dezoito dessas escolas em dez Estados brasileiros, trabalhando com a Pedagogia da Alternância. Desde o seu surgimento até o ano de 2001, as EFAs de EM e EP haviam formado 88 turmas, num total de 1.977 técnicos em agropecuária.

Para situar a implantação da Pedagogia da Alternância no Brasil, através do nascimento dos Centros Familiares de Formação por Alternância (CEFFAs), este estudo apresenta uma contextualização da relação entre agricultura familiar, educação no Brasil e o movimento de articulação por uma Educação do Campo. Os CEFFAs surgiram no Brasil a partir das experiências francesas e italianas, por isso descreve-se o surgimento e o desenvolvimento das Casas Familiares Rurais francesas e a organização internacional atual dos centros educativos que trabalham com a pedagogia da alternância.

Em busca dos princípios fundamentais construídos pelos CEFFAs, foi necessário recorrer a estudos sobre a alternância na 
formação e as contribuições de Freire sobre a educação problematizadora, de Gramsci sobre a escola unitária e de Pistrak sobre a escola do trabalho.

O estudo conclui que as EFAs de EM e EP são escolas vivas em construção, que inauguram no Brasil a formação dos jovens agricultores familiares em alternância, de maneira integrada e unitária, contando com uma crescente participação e responsabilidade dos agricultores familiares e contribuindo para o fortalecimento e o desenvolvimento da agricultura familiar. Assim participam da construção da Educação do Campo no Brasil e fazem parte de um conjunto maior de movimentos e organizações que historicamente tem lutado contra a concentração da terra, do poder e do saber no Brasil e da construção da reforma agrária, da democracia e da cidadania.

Palavras-chave: agricultura familiar, pedagogia da alternância, ensino médio, educação profissional 